\title{
Brainstem PML lesion mimicking MS plaque in a natalizumab-treated MS patient
}

Figure $1 \quad$ Baseline MRI scans
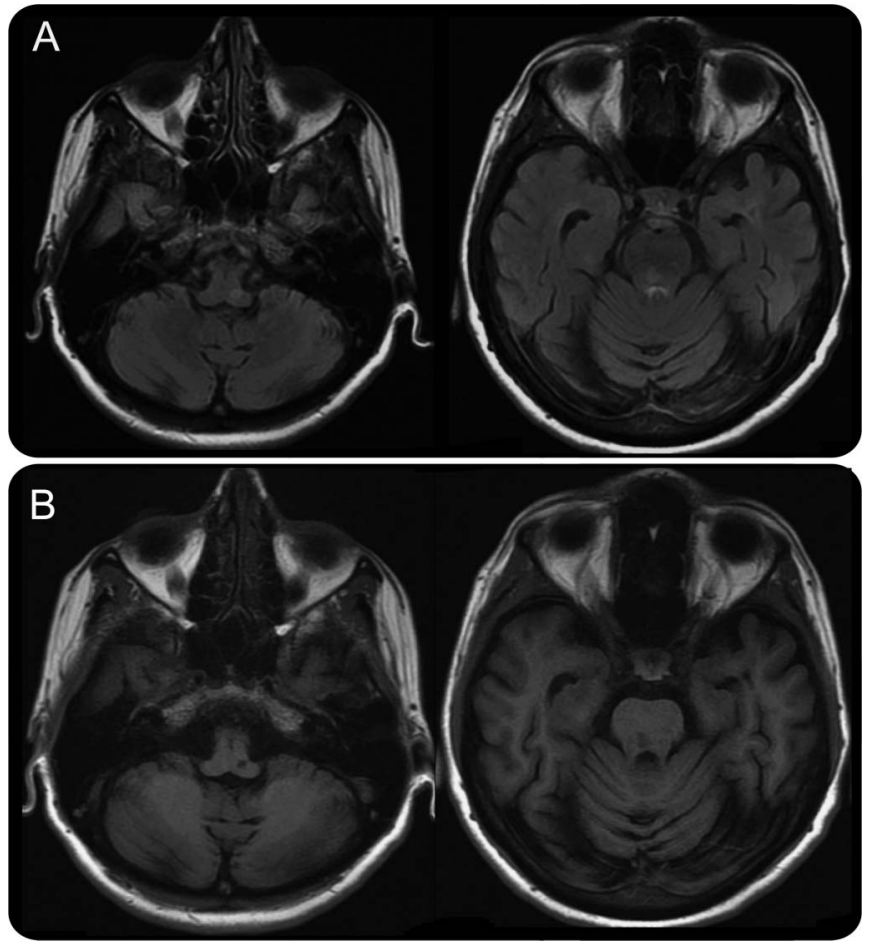

Axial images show pons and medullary fluid-attenuated inversion recovery-hyperintense lesions (A). The lesions appear markedly hypointense on T1-weighted scans (B).

A 47-year-old woman with relapsing-remitting multiple sclerosis (MS), treated with natalizumab for 14 months, reported dysphagia. Brain MRI demonstrated small fluid-attenuated inversion recovery-hyperintense T1-hypointense unenhancing lesions of the right pons and left medulla initially interpreted as new MS plaques (figure 1), but increased and became confluent over 3 months (figure 2). CSF demonstrated the presence of JC virus (4,015 DNA copies).

Brainstem progressive multifocal leukoencephalopathy (PML) is rare in comparison to brainstem $\mathrm{MS}^{1,2}$ and is a diagnostic challenge in patients treated with disease-modifying therapy. Early marked T1 hypointensity, diffusion-weighted imaging hyperintensity, and close MRI follow-up may distinguish new MS activity from PML.

Carla Tortorella, $M D$, PhD, Vita Direnzo, MD, Mariangela D'Onghia, MD, Maria Trojano, $M D$

From the University of Bari, Italy.

Author contributions: C. Tortorella, V. Direnzo, and M. D'Onghia reviewed the clinical case and interpreted the data. C. Tortorella interpreted the data and wrote the manuscript. M. Trojano commented on and approved the final version of the manuscript.

Study funding. No targeted funding reported.

Disclosure: C. Tortorella received honoraria for speaking from Biogen-Idec, Sanofi-Aventis, Merck Serono, Novartis, Bayer-Schering, and Teva Pharmaceutical. V. Direnzo and M. D’Onghia report no disclosures. M. Trojano received honoraria for consultancy or speaking from Biogen, Sanofi-Aventis, Merck Serono, Novartis, Genzyme, Teva, and Bayer-Schering and research grants from Merck Serono, Biogen, and Novartis. Go to Neurology.org for full disclosures.

Correspondence to Dr.Trojano: maria.troiano@uniba.it 
Figure 2 Follow-up MRI scans
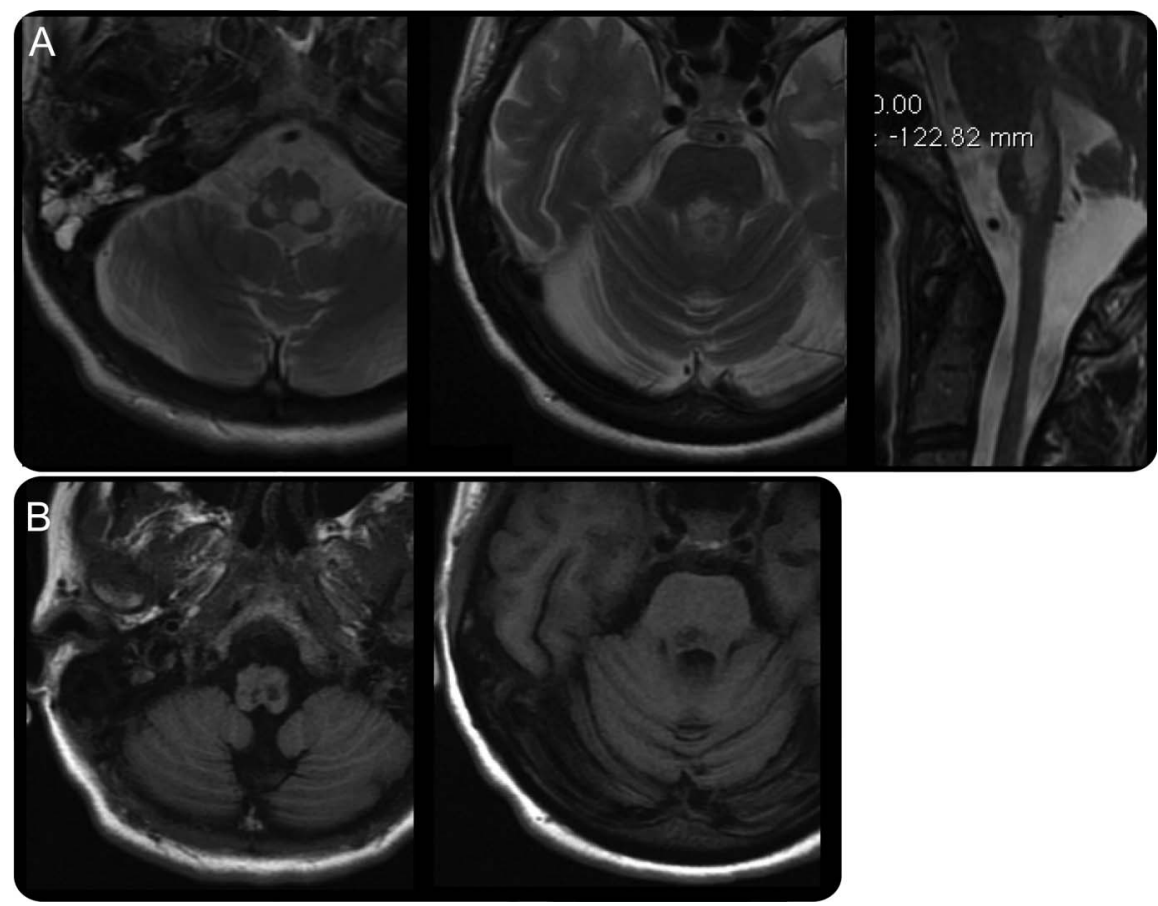

Axial and sagittal images show enlarged and confluent pons and medullary T2-hyperintense (A) and T1-hypointense lesions (B).

1. Boster A, Hreha S, Berger JS, et al. Progressive multifocal leukoencephalopathy and relapsing-remitting multiple sclerosis: a comparative study. Arch Neurol 2009;66:593-599.

2. Yousry T, Pelletier D, Cadavid D, et al. Magnetic resonance imaging pattern in natalizumab-associated progressive multifocal leukoencephalopathy. Ann Neurol 2012;72:779-787.

\section{NeuroImages Are Free at www.neurology.org!}

All Neurology ${ }^{\circledR}$ NeuroImages can now be freely accessed on the Neurology Web site. See them at www.neurology.org, where you can also sign up for journal email alerts and check out other online features, including the Resident \& Fellow section, Neurology: Clinical Practice, and the weekly Neurology Podcasts. 


\section{Neurology}

\section{Brainstem PML lesion mimicking MS plaque in a natalizumab-treated MS patient}

Carla Tortorella, Vita Direnzo, Mariangela D'Onghia, et al. Neurology 2013;81;1470-1471

DOI 10.1212/WNL.0b013e3182a84179

\section{This information is current as of October 14, 2013}

\section{Updated Information \&} Services

References

Subspecialty Collections

Permissions \& Licensing

Reprints including high resolution figures, can be found at: http://n.neurology.org/content/81/16/1470.full

This article cites 2 articles, 0 of which you can access for free at: http://n.neurology.org/content/81/16/1470.full\#ref-list-1

This article, along with others on similar topics, appears in the following collection(s):

\section{MRI}

http://n.neurology.org/cgi/collection/mri

Multiple sclerosis

http://n.neurology.org/cgi/collection/multiple_sclerosis

Information about reproducing this article in parts (figures,tables) or in its entirety can be found online at:

http://www.neurology.org/about/about_the_journal\#permissions

Information about ordering reprints can be found online:

http://n.neurology.org/subscribers/advertise

Neurology ${ }^{\circledR}$ is the official journal of the American Academy of Neurology. Published continuously since 1951, it is now a weekly with 48 issues per year. Copyright () 2013 American Academy of Neurology. All rights reserved. Print ISSN: 0028-3878. Online ISSN: 1526-632X.

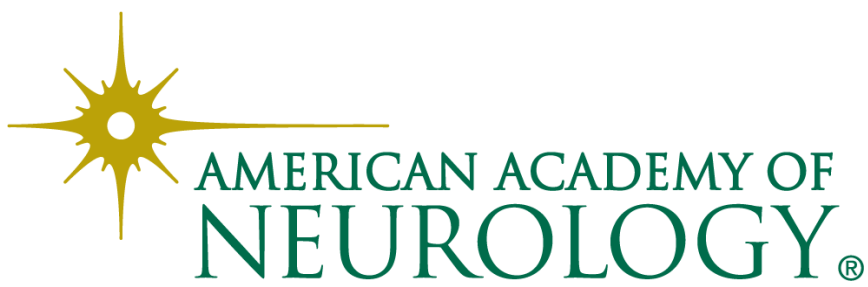

